\title{
長方形断面をもつ高層建築物の風直角方向振動時の非定常風圧力 UNSTEADY AERODYNAMIC PRESSURES ON RECTANGULAR HIGH-RIZE BUILDINGS OSCILLATING IN THE TRANSVERSE DIRECTION
}

\author{
丸山勇祐*, 谷池義人**, 西村宏昭*** \\ Yuusuke MARUYAMA, Yoshihito TANIIKE and Hiroaki NISHIMURA
}

\begin{abstract}
To consider aeroelastic instabilities of prismatic high-rise buildings in strong winds, unsteady aerodynamic forces must be investigated as the external forces acting on buildings. In the previous paper we presented the characteristics of fluctuating pressures on side face of the oscillating square prism (depth-breadth ratio $D / B=1$ ). This paper presents the characteristics of fluctuating pressures of other two type rectangular prisms, which are flow reattachment model $(D / B=2)$ and complete se paration model ( $D / B=0.5$ ). And the comparison of three type prisms(square and two type rectangular prisms) is discribed. The characteristics of the pressures on the lower parts of square prism are similar to that of $D /$ $B=0.5$ rectangular prism, on the other hand the characteristics of the pressures on the higher parts of spuare prism are similar to that of $D / B=2$ rectangular prism.
\end{abstract}

Keywords : aeroelastic instability, unsteady a erodynamic force, fluctuating pre ssure, complete separation, flow reattachment, forced oscillation technique

空力負減衰, 非定常空気力, 変動風圧, 完全剥離, 流れの再付着, 強制振動法

1.はじめに

高層建築物のような3 次元構造物では、接近流のみならず建物 自ら発生する渦によって空力不安定振動を引き起こす要因となる 非定常空気力も高さ方向に変化する。高層建築物の振動の抑制や 耐風設計を考える際に、建物各部に作用する非定常空気力を明ら

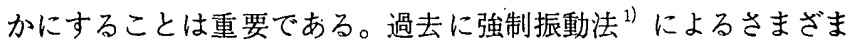
な非定常空気力に関する研究成果が報告されているが、2次元的

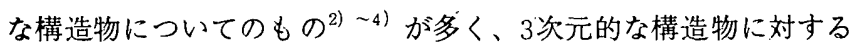
研究 ${ }^{5)}$-s) は数が少く、その解明は充分とはいいがたい。筆者等 9）10)は、以前に正方形断面をもつ3次元角柱の側面に働く非定常 空気力を強制振動実験から求めている。この結果から上層部と下 層部に㗢く空気力に違いのあることを示した。建物上層部ではカ ルマン渦の影響をあまり受けず準定常的な考えが適用できること を示し、下層部ではカルマン渦の発生周波数と角柱の振動数の一 致する共振風速付近で急激に空力負減衰効果が生じることを示し た。正方形断面の角柱は前縁での剥離流が上層部で完全剥離し、 下層部で再付着するため上記のような複雑な現象が見られた。本 報では、前縁剥離流が完全剥離する場合と再付着する場合の非定 常空気力に対する影響を明らかにするために、剥離剪断層の挙動
が明確である2種類の長方形断面角柱について同様の強制振動実 験を行った。この結果から自励的渦励振や低風速励振などの空力 不安定振動を起こす原因となる非定常な空気力と角柱周りの流れ 場との関係を明らかにしている。さらに、長方形断面に関する実 験結果を解析することにより、高層建築物の非定常風圧力に関し てより一般的な基礎データを示すことができた。

\section{2.実呀方法}

日本建築総合試験所の幅 $1.8 \mathrm{~m}$ 、高さ $1.5 \mathrm{~m}$ の測定断面をもつエッ フェル型吹出式境界層風洞を用いて実験を行った。今回の実験で は一様流に近い流れ場を対象としたので、接近流はラフネス等を 用いず床面で十分に発達させた境界層乱流とした。接近流の性質 を図 1 に示す。平均風速の鉛直分布がべき指数 $\alpha=0.14$ 、低層部 における乱れの強さが $10 \%$ の厚さ $15 \mathrm{~cm}$ の境界層流である。実験 は風洞内で模型を風直角方向に強制振動させ、その側面に働く変 動風圧を測定した。

強制振動装置(図2)は、既報9)10)で用いたものを使用した。こ の装置は、パルスモータによる回転運動をカムを介して風直角方

既発表先：京都大学防災研究所年報 Vol.39 1996 大会学術講演会 (近畿) 1996.9

* 京都大学工学研究科建築学専攻 大学院生 - 工修 $\quad$ Graduate Student, Dept. Architecture, Faculty of Engineering, Kyoto.University,

***大阪市立大学工学部建築学科 教授・工博

*** 日本建築総合試験所 室長 M. Eng.

Prof., Dept. Architecture, Faculty of Engineering, Osaka City University, Dr. Eng. General Building Research Corporation 


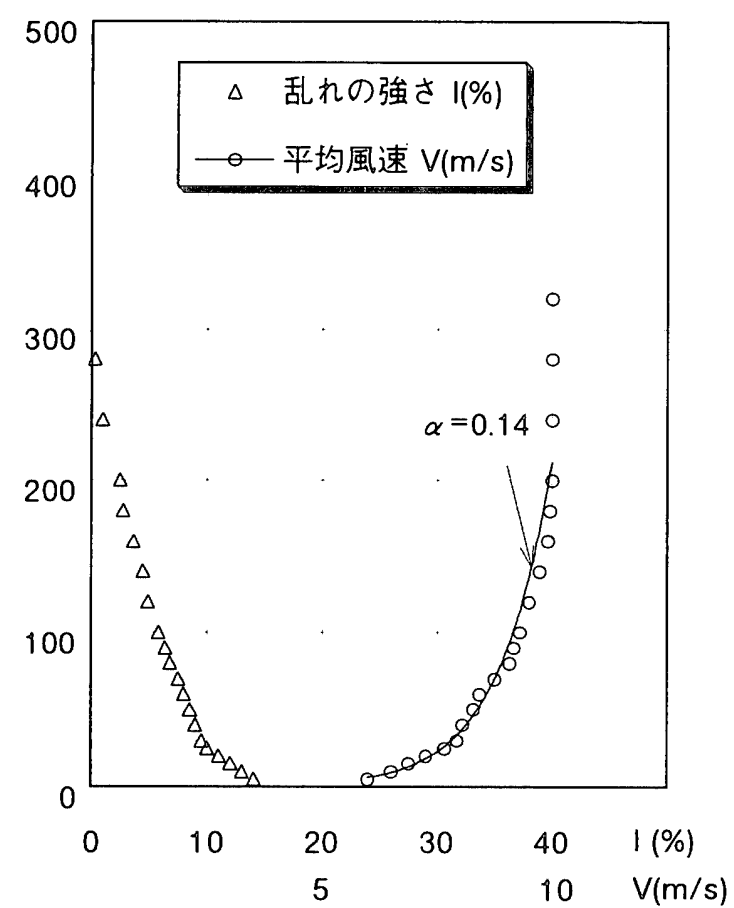

図1 接近流の平均風速と乱れの強さ

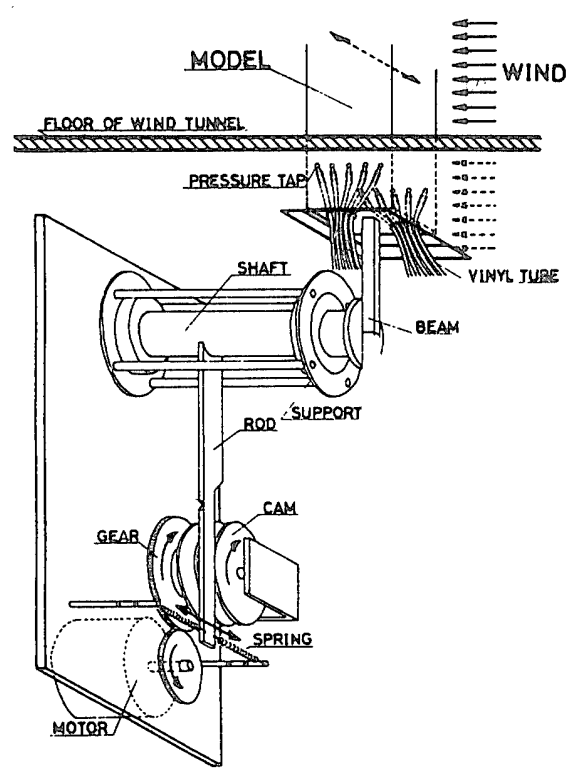

図2強制振動装置

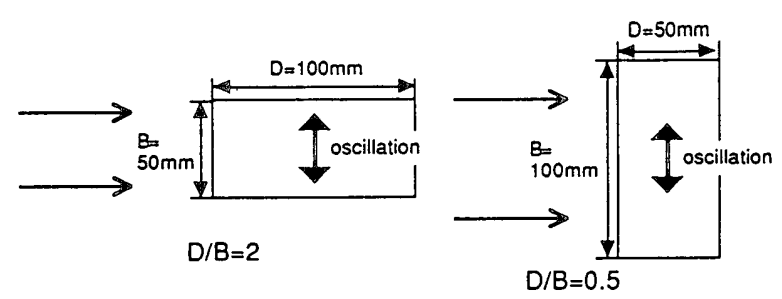

図3 角柱模型断面図
向のロッキング振動に変換し、カムによって振動振幅を変えられ るようにしてある。模型の振動形態は1次の直線モードになる。 強制加振振幅は建物の層間変位角 $\mathrm{y}_{\mathrm{r}}$ で表わし、0.004、0.008、 0.016の3 種類とした。また強制振動の振動数は $\mathrm{fm}=8.1 \mathrm{~Hz}$ である。 角柱の振動変位は振動装置下部に設置したレーザー変位計により 測定した。実験模型は図 3 に示すように断面が幅 $\mathrm{B}=50 \mathrm{~mm}$ 、奥行 $き \mathrm{D}=100 \mathrm{~mm}$ （辺長比 $\mathrm{D} / \mathrm{B}=2$ ）の風向方向に細長いものと、幅 $\mathrm{B}=$ $100 \mathrm{~mm}$ 、奥行き $\mathrm{D}=50 \mathrm{~mm}$ （辺長比 $\mathrm{D} / \mathrm{B}=0.5 ）$ の風直角方向に細長 いものの2種類の長方形断面角柱を用いた。また角柱の高さは $350 \mathrm{~mm}$ で、アスペクト比は $\mathrm{H} / \sqrt{\mathrm{BD}}=5$ である。実験風速は、角柱 頂部で無次元風速 $\mathrm{Vr}(=\mathrm{V} / \mathrm{fm} \sqrt{\mathrm{BD}})=3 \sim 14$ の範囲とした。

変動風圧の測定は、角柱側面に設けた縦方向8点、横方向6点、 合計 48 点の圧力測定孔から、長さ $60 \mathrm{~cm}$ のビニールチューブを介 して圧力センサーにつないで行った。使用した圧力計は差圧型の もので、10mmAqで1Vの出力をする。ビニールチューブ使用によ る誤差は以下のようにデジタル的に補正した。解析領域の $40 \mathrm{~Hz}$ 付 近までゲイン要素に関してはフラットだったので補正を行わず、 位相美に関しては、 $40 \mathrm{~Hz}$ 付近までほぼ直線的にずれることを確認 し、一定時間 $(0.002 \mathrm{sec})$ だけ波形をずらすことにより補正を行っ た。

\section{3.変動風圧のスペクトル解析}

角柱側面に働く変動風圧の主成分を調ベるため、スペクトル解 析を行った。図4、図5は代表的な点でのパワースペクトルを静止 時と、振動時の 4 種類の風速について示している。横軸は周波数 $(\mathrm{Hz})$ 、縦軸は各周波数のパワーを $20 \mathrm{~Hz}$ までの全パワーで割ってパー セントで表示したものである。周波数領域での分解能は、サンプ リング周波数を $100 \mathrm{~Hz}$ 、デー夕数を 1024 点としているので、 $0.0976 \mathrm{~Hz}$ である。また結果は16回のアンサンブル平均を行って 认る。図中の $\mathrm{fm}, \mathrm{fs}$ とあるのは角柱の振動数 $\mathrm{fm}$ と角柱後方に発生す るカルマン渦の発生周波数舐を表わす。

図4は、辺長比2の角柱についての結果である。スペクトル解析 の結果、振動振幅による差はほとんど見られなかったので、ここ では $\mathrm{y}_{\mathrm{r}}=0.008 の も の と$ 角柱静止時のものについてのみ結果を示す。 角柱静止時にはどの点においてもはっきりしたピークが見られな い。これは流れの再付着により角柱前縁の剥離流によって形成さ れるカルマン渦が弱められるためであると思われる。高風速時に 得られるスペクトルピークからストローハル数 $\mathrm{St}\left(=\mathrm{f}_{\mathrm{s}} \cdot \sqrt{\mathrm{BD}} / \mathrm{V}\right.$ 、 fsはピークを示す周波数)を計算すると、 $\mathrm{St}=0.111$ になった。これ より、カルマン渦の発生周波数と角柱の振動数が一致( $\mathrm{fs}=\mathrm{fm})$ する 無次元共振風速は $V_{\text {RES }}(=1 / \mathrm{St})=9.0$ となる。振動時には、角柱側 面全面で角柱の振動数成分（fm成分）が卓越し、ストローハル数 成分( $\mathrm{fs}$ 成分)はほとんど見られない。中層部および下層部ではわず かに的成分と思われるものが見られるが、值がばらついていて明 確なピークは見られない。fs成分が見られないのは、静止時と同 じく流れの再付着により角柱後方のカルマン渦が弱まることによ ると思われる。共振風速付近ではピークを示すパワーはかなり大 きくなっているが、これは $\mathrm{fm}$ 成分と $\mathrm{fs}$ 成分の一致する同期現象に よると思われる。この現象も下層部のほうがより明確に見られる。 


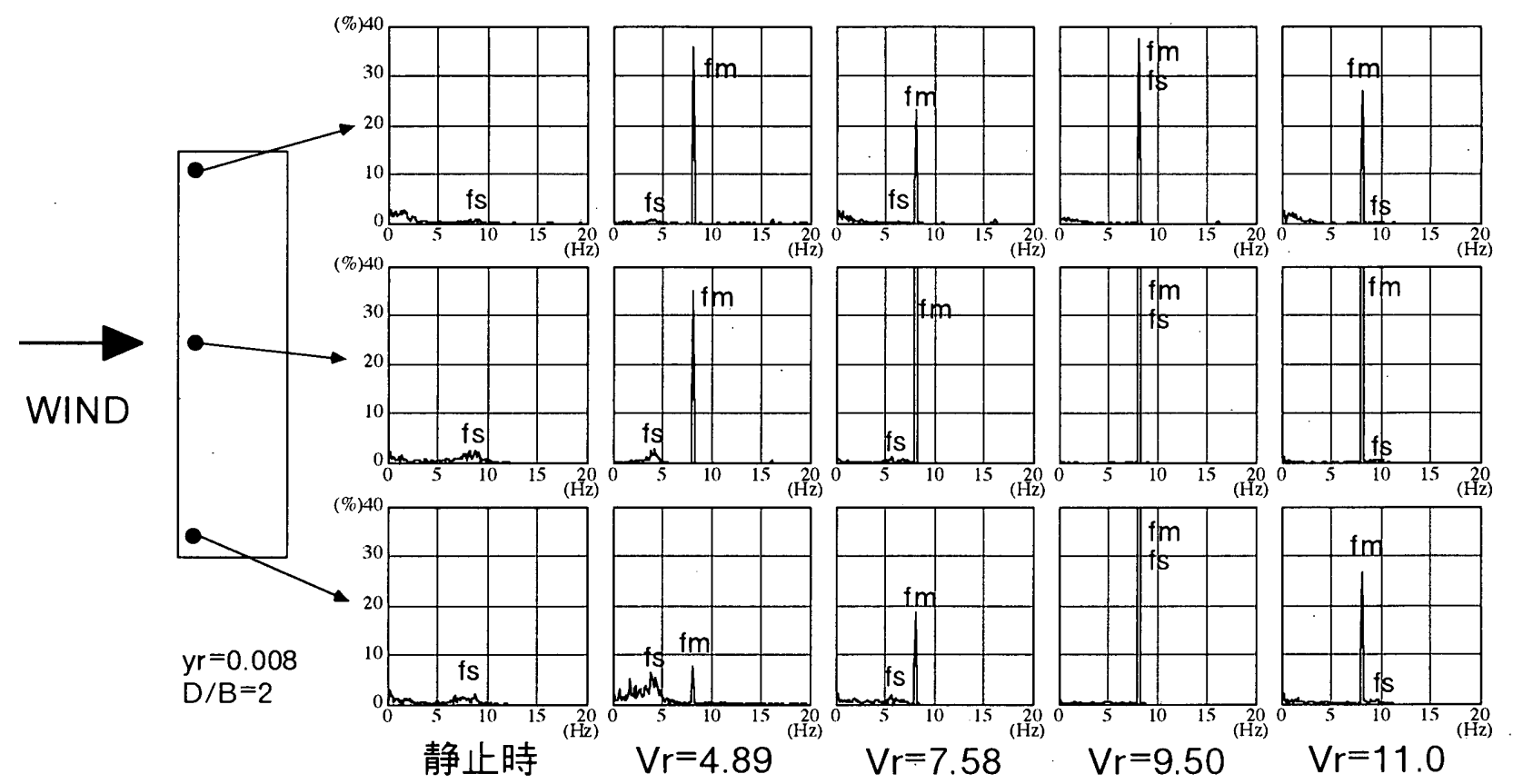

図4 変動風圧のパワースペクトル $(\mathrm{D} / \mathrm{B}=2)$

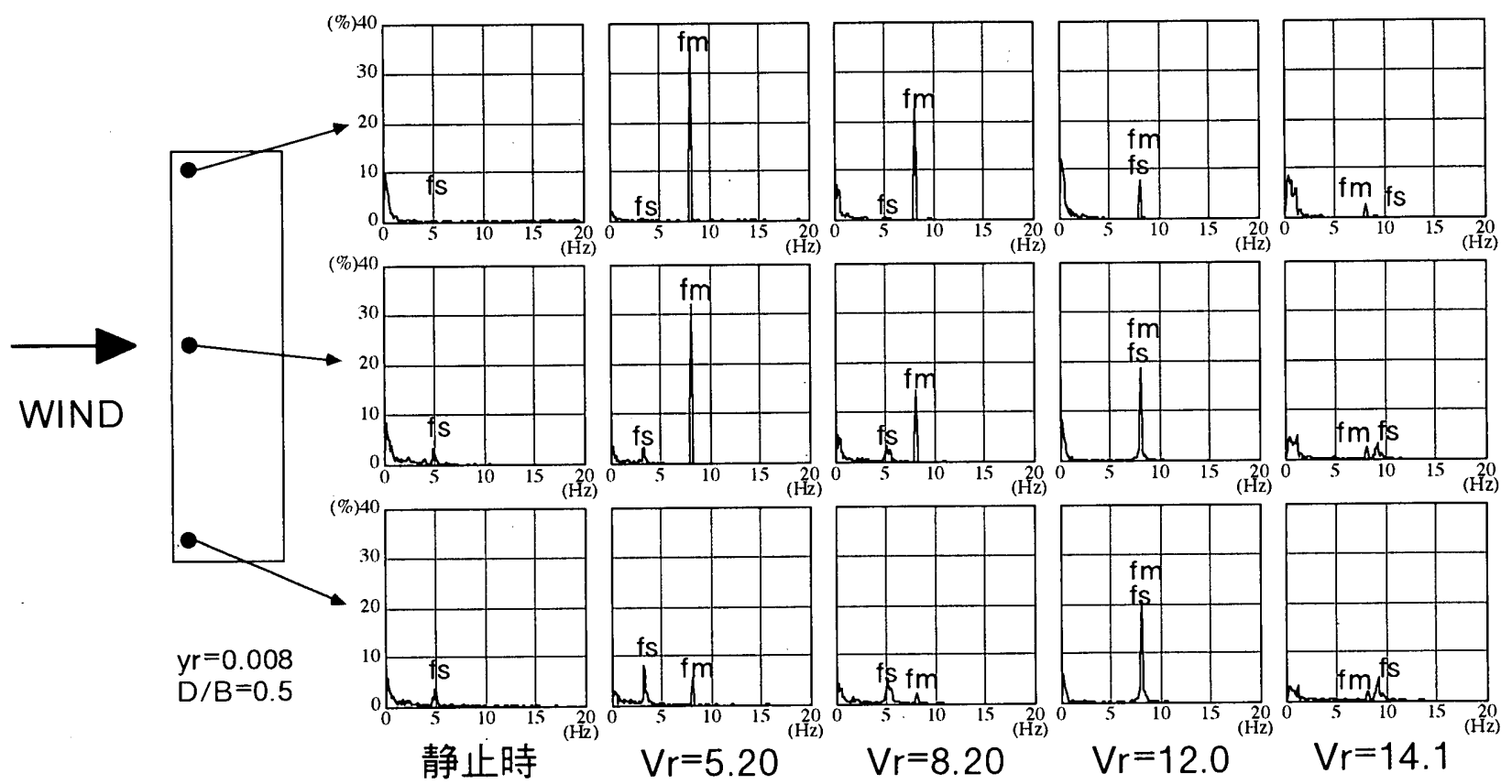

図5変動風圧のパワースベクトル $(\mathrm{D} / \mathrm{B}=0.5)$

共振風速を超えてからもしばらく同期現象は見られるが、 $\mathrm{Vr}=$ 11.0 付近から $\mathrm{fm}$ 成分のピークが弱まって、共振風速以下のときと 同じ傾向になる。

戝5は、辺長比0.5の角柱についての結果である。振動振幅によ ろ差はほとんど見られなかったので、ここでは $\mathrm{y}_{\mathrm{r}}=0.008$ ものと 角柱静止時のものについてのみ結果を示す。角柱静止時には、上 層部ではっきりしたピークが見られず、中層部および下層部では 明瞭なスペクトルピークが見られる。スペクトルピークを示す周 波数は、中層部、下層部とも同じであり、これからストローハル 数Stを計算すると、 $\mathrm{St}=0.083$ になった。れより、カルマン渦の 発生周波数と角柱の振動数が一致 $\left(\mathrm{fS}_{\mathrm{S}}=\mathrm{fm}\right)$ する共振風速は $\mathrm{V}_{\mathrm{RES}}(=1)$ $\mathrm{St})=12.0$ となる。振動時には、上層部では常に fm成分が卓越し、 fs成分は相対的に小さくなっている。静止時にも上層部で的成分 のはっきりしたピークが見られなかったことから、剥離にともな う渦が上層部では拡散して弱まっていると考えられる。また上層 部では振動振幅が大きいため、振動に伴う圧力変動の影響が強く より強くあらわれることも考えられる。中層部ではfm成分、 fs 成 分の両方のピークが見られるが、低風速時にはfm成分のほうが卓 越している。共振風速付近では角柱の振動数 $\mathrm{fm}$ とカルマン渦の発 生周波数fsの一致によりビークを示すパワーは大きくなる。共振 風速を超えてもしばらくは䞌成分が明確に見られないが、これは 同期現象が続いているためだと思われる。共振風速を超えてから はfs成分が卓越し $\mathrm{fm}$ 成分は小さくなる。下層部では中層部同様に 两方のピークが見られるが、低風速ではfs成分がかなり卓越して 

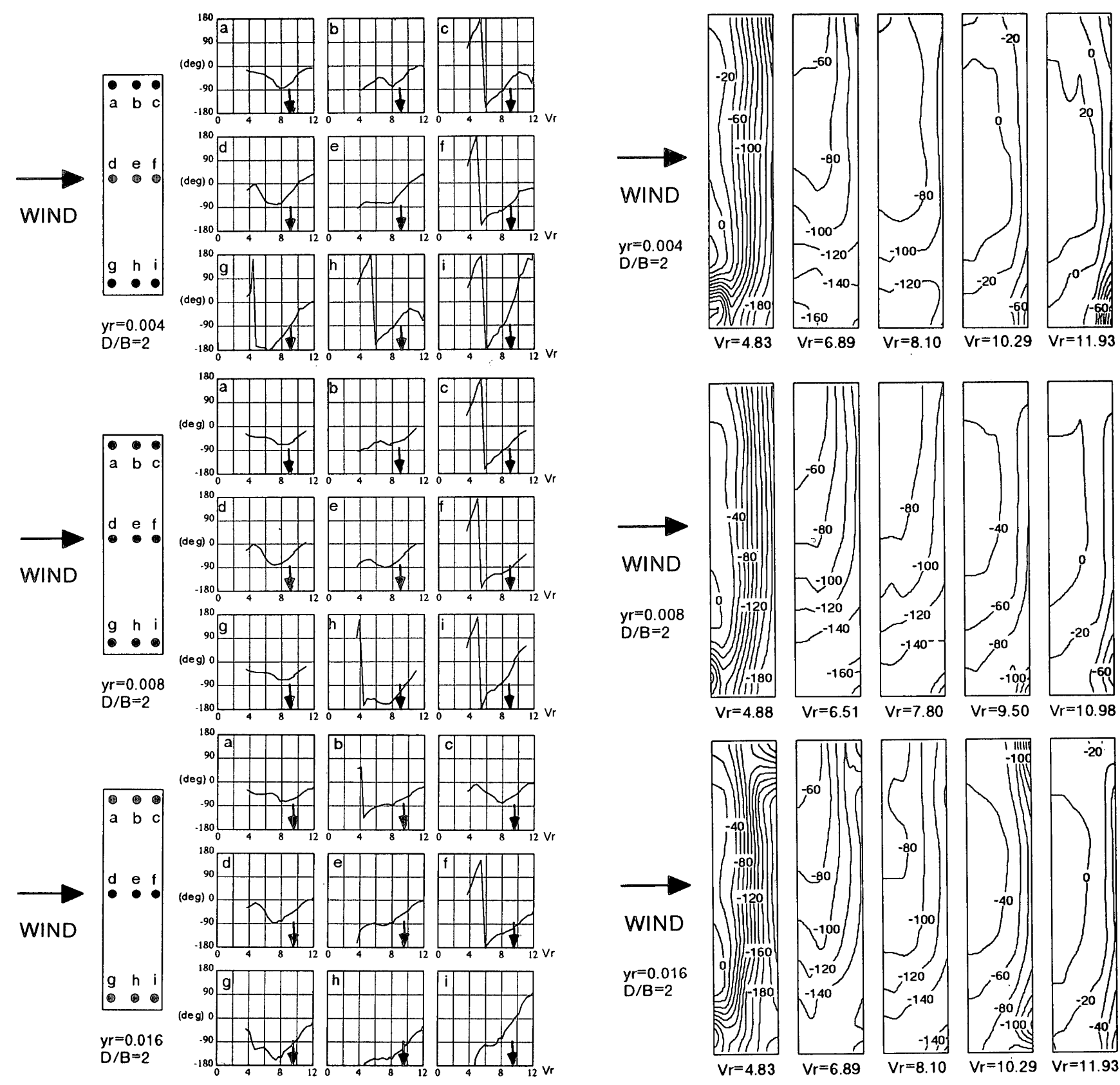

図6 変動風圧と振動変位の位相差 $\beta_{i}$ の風速による変化 $(\mathrm{D} / \mathrm{B}=2)$

いる。風速の増加とともに $\mathrm{fm}$ 成分のピークが大きくなり、共振風 速付近ではピークを示すパワーはかなり大きくなる。共振風速時 には下層部では上層部、中層部と比較して $\mathrm{fs}$ 成分の占める割合が かなり大きくなるのは、かなり強い渦が下層部でつくられている ためだと思われる。共振風速を超えても中層部同様にしばらく同 期現象が続く。共振風速を超えてからはfm成分は小さくなる。

\section{4.变動風圧のなす仕事量}

\section{1仕事量の定柾}

角柱側面の各測定点で得られた変動風圧より振動に寄与する空 気力(非定常空気力)を取り出すことを考える。非定常空気力の検 出は既報 ${ }^{12)}$ と同様に、ある点（j点）における変動風圧が角柱に なす仕事量 $\mathrm{W}_{i}$ を(1)式のように計算することによって行った。

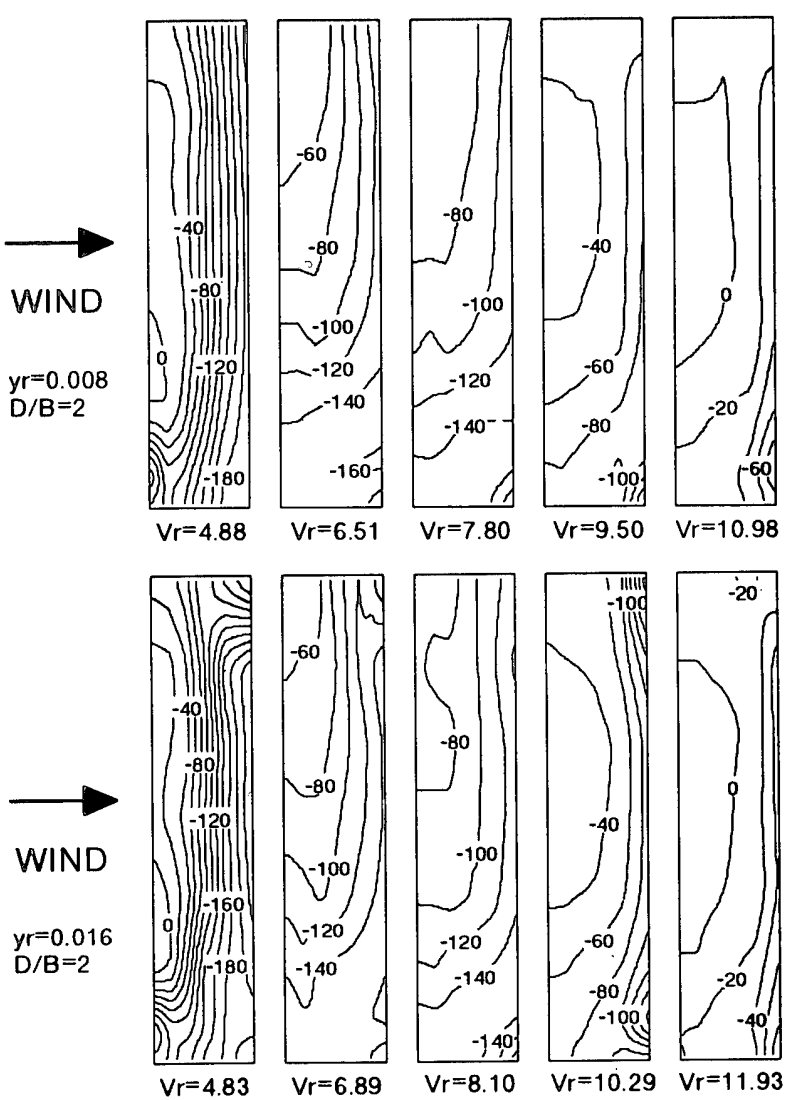

図7 変動風圧と振動変位の位相差 $\beta_{i}$ の分布 $(\mathrm{D} / \mathrm{B}=2)$

$W_{j}=\int_{0}^{1 / t_{m}} P_{j}(t) \cdot d y_{j}=\pi y_{0 j} P_{0 j}^{\prime} \sin \beta_{j}$

上式において $P_{j}(t)$ はj点での変動風圧(ただし、平均成分を除 〈)、 $\mathrm{y}_{\mathrm{j}}(\mathrm{t})$ はその点での水平変位である。また $\mathrm{y}_{0 \mathrm{j}}$ はj点での振動振幅 であり、 $\mathrm{P}^{\prime}{ }_{0 \mathrm{j}}$ はj点に作用する変動風圧の $\mathrm{fm}$ 成分の振幅である。 $\beta$; は変動風圧と振動変位との位相差を示し、 $\beta_{i}>0$ のとき、変動風 圧は変位に対して位相の進みをもつ。等 ${ }_{0 j} v \mathrm{y}_{0 j}$ は正であるから、 $\mathrm{W}_{\mathrm{i}}$ の正負は $\sin \beta_{\mathrm{j}}$ の符号によって決まる。 $\mathrm{W}_{\mathrm{i}}>0$ になる場合 $\mathrm{j}$ 点に 加わる変動風圧のなす仕事は、角柱にエネルギーを与え振動を増 大させる。側面全体の測定点に加わる変動風圧が、1サイクルあ たりに角柱に対してなす仕事量の総和 $\mathrm{W}_{\mathrm{T}}$ は次式となる。

$\mathrm{W}_{\mathrm{T}}=\sum_{\mathrm{j}=1}^{\mathrm{n}} \mathrm{a}_{\mathrm{j}} \mathrm{W}_{\mathrm{j}}$

ここで $a_{\mathrm{i}}$ は、 $\mathrm{j}$ 点の変動風圧が分担する面積を示す。 $\mathrm{W}_{\mathrm{T}}$ が正にな 

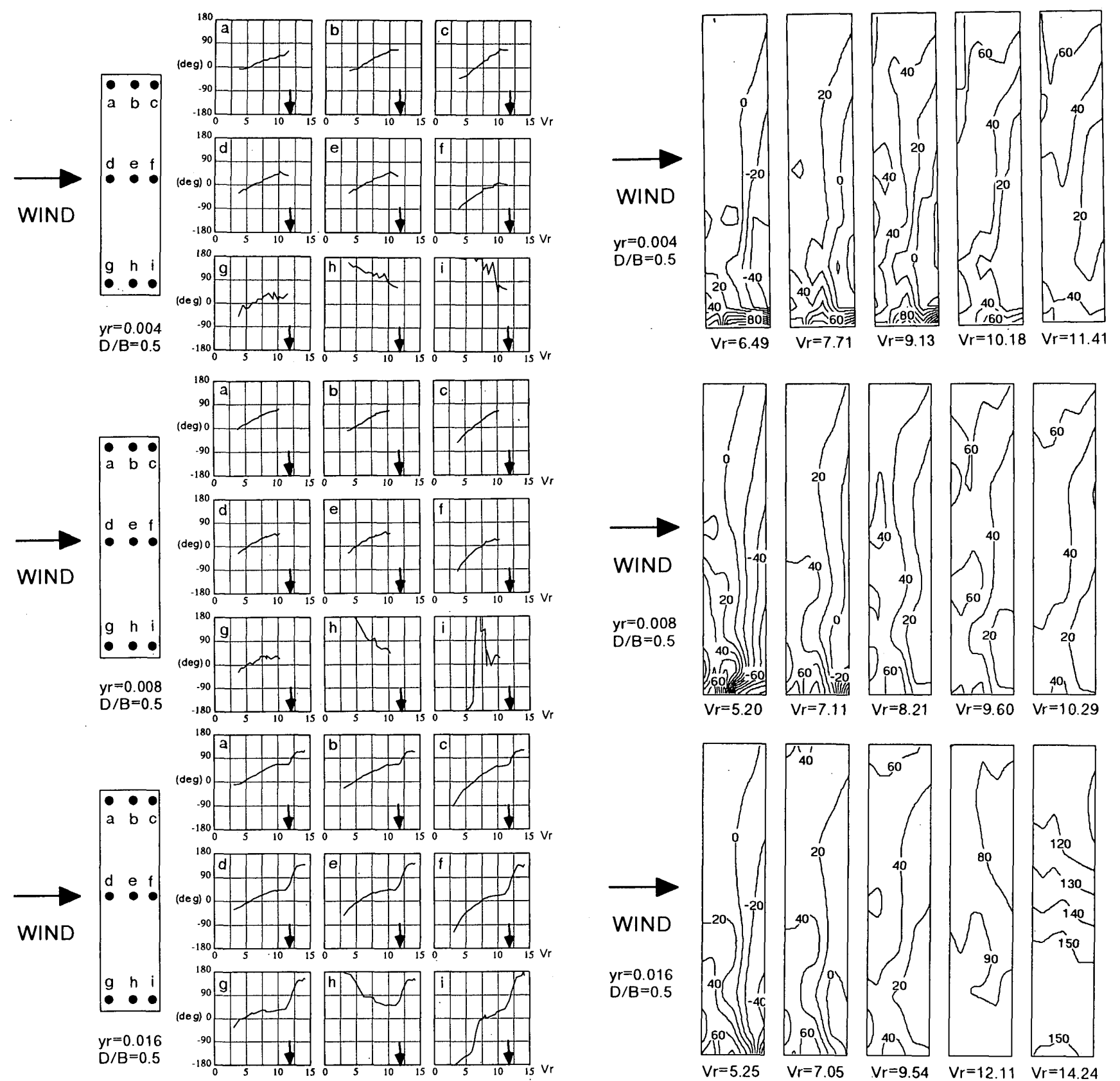

図8 変動風圧と振動変位の位相差 $\beta_{i}$ の風速による変化 $(\mathrm{D} / \mathrm{B}=0.5)$

るとき、角柱側面は空気からエネルギーを与えられることになり、 振動を促進する力、つまり負減衰力を受ける。この空気力が風直 角方向の空力不安定振動の原因となる。

\section{2風方向に細長い角柱（辺長比2）の位相差 $\beta_{i}$}

図6は辺長比2の角柱側面に働く変動風圧と振動変位の位相差の 風速による変化を代表的な点において表わしたものである。ここ で位相差 $\beta_{i}$ は変位の周期を基準に $-180^{\circ}<\beta_{\mathrm{i}} \leqq 180^{\circ}$ の範囲で表 わしている。横軸は無次元風速Vrで表わしている。図中の矢印

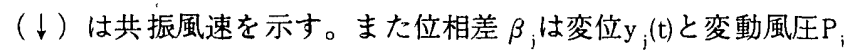
(t)の相互相関係数が最大となるてから求めたものである。

まず3種類の振幅で共通してみられた位相差 $\beta_{i}$ の変化の傾向に ついて述べる。上層部（図中の点 $a, b, c$ ）および風上側（図中の点 a,d,g）では同じょうな傾向が見られる。共振風速 9.0 の約半分の無

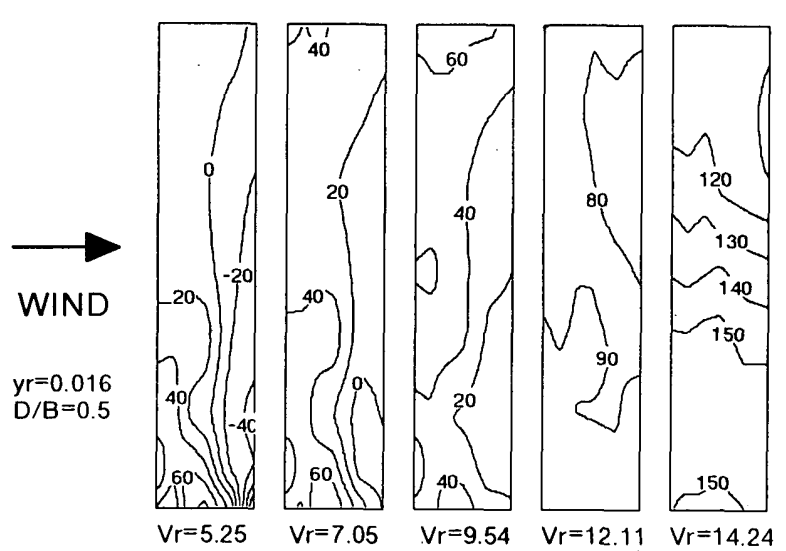

図9 変動風圧と振動変位の位相差 $\beta_{\mathrm{i}}$ の分布 $(\mathrm{D} / \mathrm{B}=0.5)$

次元風速 $\mathrm{Vr}=4 \sim 5$ 付近で極大值をもち、風速の增加とともに位相 差 $\beta$; が小さくなり無次元風速 $\mathrm{Vr}=7 \sim 8$ 付近で負の值のピークとなっ ている。それ以上の風速になると風速の増加とともに位相差 $\beta_{j}$ の 值も大きくなるが $\beta_{j}>0$ となる部分はほとんど見られない。共振 風速 $\mathrm{Vr}=9$ 付近では明確な変化は見られなかったが、共振風速よ り高風速の領域では風上の中層部（d点）で $\beta_{\mathrm{j}}>0$ となる部分がわ ずかにみられた。風下側の下層部（図中の点 $\mathrm{f}, \mathrm{h}, \mathrm{i}$ ) で゙は風速の增 加とともに位相差 $\beta$ ，も単調に増加している。無次元風速 $\mathrm{Vr}=7 \sim 8$ 付近でやや傾きが緩くなる部分も見られるが、ほほ直線的に変化 している。位相差 $\beta_{i}$ の值は増加しているが点以外では $\beta_{j}>0$ とな る部分は見られなかった。また共振風速 $\mathrm{Vr}$ 二付近については、明 確な変化は見られなかった。また風下側の点（点 $\mathrm{c}, \mathrm{f}, \mathrm{i}$ ) では次元 風速 $\mathrm{Vr}=4 \sim 5$ 付近で $\beta_{\mathrm{j}}>0$ となっている点がみられた。この傾向 は振幅の小さい $\mathrm{y}_{\mathrm{r}}=0.004,0.008$ の場合に顕著である。角柱中央の 
点の位相差 $\beta_{i}$ は2つの傾向を併せもったような変化を示している。 位相差 $\beta_{i}$ の風速による変化は、上層部風下から下層部風上に向かっ て引ける対角線を境に異なった傾向が見られた。これは上層部と 下層部で流れの速度が異なるために生じると思われる。流れの速 い上層部ほど再付着点が風下側に寄っていると思われる。

、図7は辺長比 2 の角柱側面に働く変動風圧と振動変位の位相差 $\beta_{i}$ の分布を代表的な風速において表わしたものである。振動振幅に よる差はあまりなかったが、振幅の小さなものほど高風速域にお いて位相差 $\beta_{\mathrm{j}}>0$ となる領域が広くなっていた。風速の低いとき は、流れが伝わるのに時間がかかるため風上と風下で位相に大き な差ができた。風下では $\beta$; $<-180^{\circ}$ となる部分が見られるが、 これが低風速励振の要因になるものと思われる。風速の増加とと もに上層部の風上側から位相差 $\beta{ }_{j}$ が大きくなり、上層部の風上側 を中心に放射状に変化する分布となった。共振風速を超えるあた りから上層部と下層部の差はほとんどなくなり風上から風下にか けて位相差 $\beta$ 方が小くなる傾向になる。これは側面全面で再付着 が起こらなくなったからだと思われる。このとき下層部の風下側 で極端に $\beta_{j}$ が小さくなっているがこの部分だけ再付着が起こって いるものと思われる。この風速域で $\mathrm{y}_{\mathrm{r}}=0.004$ の振幅の位相差 $\beta$; は かなりの部分で正となっているが、振幅が大きい $\mathrm{y}_{\mathrm{r}}=0.008,0.016$ のときには＜＜の部分が多い。この傾向は後で述べる仕事量の総 和にもみられる。このことから、風方向に細長い建物では共振風 速を越えた風速域でも振幅がそれほど大きくならないことが予測 される。

\section{3風直角方向に細長い角柱（辺長比0.5）の位相差 $\beta$}

図8は辺長比 0.5 の角柱側面に働く変動風圧と振動変位の位相差 の風速による変化を代表的な点において表わしたものである。図 の表示は図6と同様である。ただし $\mathrm{y}_{\mathrm{r}}=0.016$ の場合のみ共振風速 まで測定しているが、 $\mathrm{y}_{\mathrm{r}}=0.004,0.008$ に関しては無次元風速 $\mathrm{Vr}=$ 12 付近までしか測定していない。振動振幅の違いによる位相差 $\beta$; の変化は、共振風速 $\mathrm{V} r=12.0$ 以下ではあまり見られなかったので $\mathrm{y}_{r}=0.016$ の傾向について述べる。

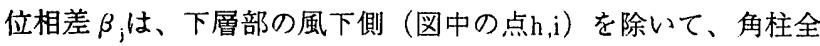
面でほほ同じような傾向が見られる。共振風速以下では、風速の 増加とともに位相差 $\beta_{j}$ も直線的に増加している。また位相差 $\beta_{j}$ の 值は無次元風速 $\mathrm{Vr}=4 \sim 5$ 付近で正となっている。無次元風速 $\mathrm{Vr}=$ 10 付近から $\beta_{j}$ の増加は緩やかになるが、共振風速付近で急激に大

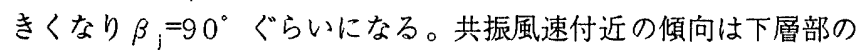
風下側にも見られる。下層部の風下側の傾向は明確ではないが点 は他の上層部の点ともよく似ている。

図9は辺長比0.5の角柱側面に働く変動風圧と振動変位の位相差 $\beta_{j}$ の分布を代表的な風速において表わしたものである。振動振幅 による差はあまりなかったので $\mathrm{y}_{\mathrm{r}}=0.016$ 傾向について述べる。 風速の低いときは、風上側で $\beta_{j}>0$ 、風下側で $\beta_{j}<0$ となってい る。風速の增加とともに $\beta_{j}>0$ の領域が風下側に広がっていき、 無次元風速 $\mathrm{Vr}=7$ 付近で側面全体が $\beta_{j}>0$ となっている。風上側の ほうが位相差 $\beta_{j}$ の值は大きくなっていて、上層部と下層部では大 きな違いは見られない。共振風速 $\mathrm{Vr}=12$ 付近では $\beta ;$ が $90^{\circ}$ に近 い値を示す領域が側面全体に広がっている。共振風速を超えてか
らは下層部の $\beta_{\mathrm{j}}$ が大きくなり、上にいくほど小さくなっている。 上記のことから、流れが角柱前縁で剥離する風直角方向に細長い 角柱では共振風速の約1/3付近から空力不安定振動が起こりはじ め、共振風速付近ではより一層強い負減衰力を受けることが予測 される。

\section{4変動風圧のなす仕事量の総和}

図10は各点の仕事量の総和 $\mathrm{W}_{\mathrm{T}}$ を式(2)より求めた結果を示して いる。(a)は既報9１0）で求めた正方形断面角柱（辺長比1）の結果 である。(b)は風方向に細長い長方形断面角柱（辺長比2）、(c)は 風直角方向に細長い長方形断面角柱（辺長比0.5）の結果である。 横軸は無次元風速 $\mathrm{Vr}$ 、矢印は共振風速を表わしている。縦軸は仕 事量 $\mathrm{W}_{\mathrm{T}}$ を代表長さ $\sqrt{\mathrm{BD}}$ 、角柱断面積 $\mathrm{BD}$ 、速度圧 $\mathrm{q}_{\mathrm{H}}$ で無次元化し

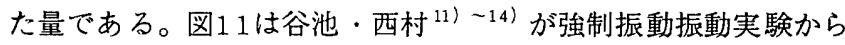
求めた非定常空気力で、これは転倒モーメントで表されている。 これと比較して、今回の結果はよく似た傾向を示している。

まず、既報9 10) で述べた正方形断面角柱の結果について簡単に まとめておく。共振風速よりも低い風速では変動風圧のなす仕事 の総和は負であり、共振風速付近で急激に増加し仕事量は正に変 化する。角柱の上層部では変動風圧と振動変位の位相差 $\beta_{j}$ は風速 とともに直線的に増加し、共振風速より低い風速においても正と なっていた。下層部では位相差 $\beta$ ：は風速とともに增加したが、共 振風速付近で急激に負から正へと変化した。このように正方形断 面角柱では、上層部と下層部で異なる空気力を受けていることを 示した。

風方向に細長い長方形断面角柱（辺長比2）では、ほとんどの 風速のときに仕事量 $\mathrm{W}_{\mathrm{T}}<0$ となっていた。無次元風速 $\mathrm{Vr}=7 \sim 8$ 付 近で負のピークとなっていて、共振風速付近から増加し始めるが、 $\mathrm{y}_{\mathrm{r}}=0.004$ の場合にわずかにW $\mathrm{T}_{\mathrm{T}}<0$ となるのがみられるだけで、 $\mathrm{W}_{\mathrm{T}}>0$ となる領域はほとんど見られなかった。これは流れが再付 着するため空気力が角柱の振動を減衰させる方向に働いていると 考えられる。無次元風速が 4 以下で $W_{\mathrm{T}}>0$ となる領域がみられる が、これが低風速励振の要因であると思われる。これは風速の低 いところでは風上側の圧力変動が風下に伝わるのが遅いので角柱 の振動とは大きな位相差が生じて起こるものだと思われる。しか

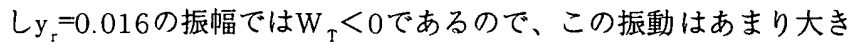
な振幅では生じないと予測される。

風直角方向に細長い長方形断面角柱（辺長比0.5）では、無次 元風速5 付近で仕事量 $\mathrm{W}_{\mathrm{T}}>0$ となり增大していく。共振風速付近 でやや仕事量が大きくなるが、共振風速を超えると減少し始める。 辺長比 0.5 の場合は、流れが角柱前縁で剥離し再付着をしないた め共振風速よりかなり低い風速で負減衰力が働くことが以下のよ うな理由で考えられる。辺長比 0.5 のように風直角方向に細長い 断面角柱では、前粶で剥離した流れによるカルマン渦は角柱後方 で形成される。そのため角柱側面に沿っての渦の流下が起こらず、 角柱側面の両側に剥離剪断層ができる。この状態で角柱が振動す ると側面の圧力分布が非対称となり、角柱が移動する側の剪断層 が接近し、振動方向への吸い込みが強くなる。その空気力は角柱 を振動方向と同じなので、振動をさらに助長するように働くと思 われる。また共振風速付近では仕事量がいっそう大きくなるが、 


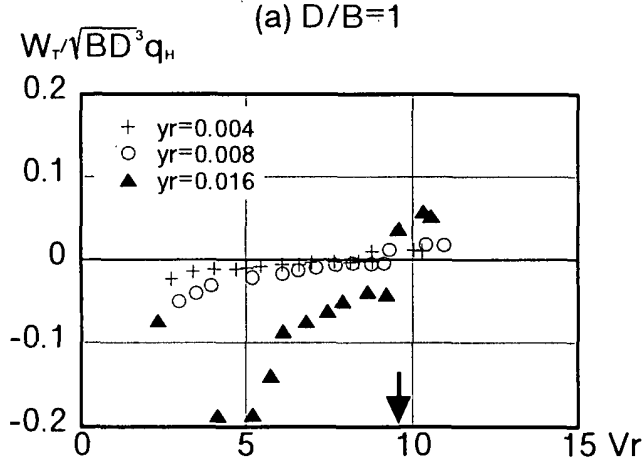

(b) $D / B=2$

$\mathrm{W}_{\mathrm{r}} \sqrt{\mathrm{BD}^{3}} \mathrm{q}_{\mathrm{H}}$

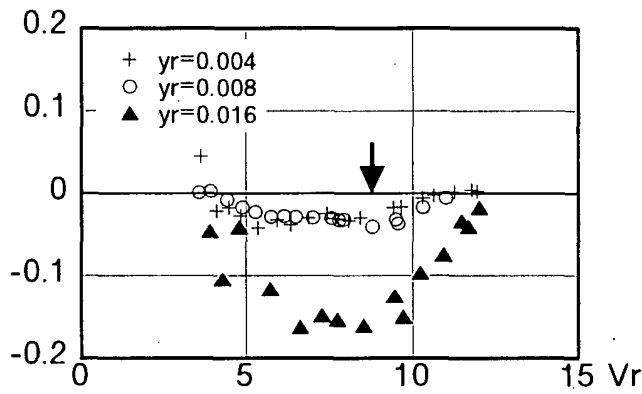

(c) $\mathrm{D} / \mathrm{B}=0.5$

$\mathrm{W}_{\mathrm{T}} / \sqrt{\mathrm{BD}}^{3} \mathrm{q}_{\mathrm{H}}$

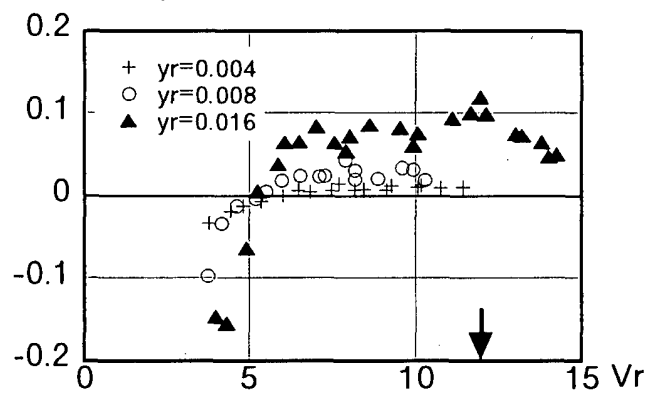

図10 角柱側面に加わる仕事量の総和
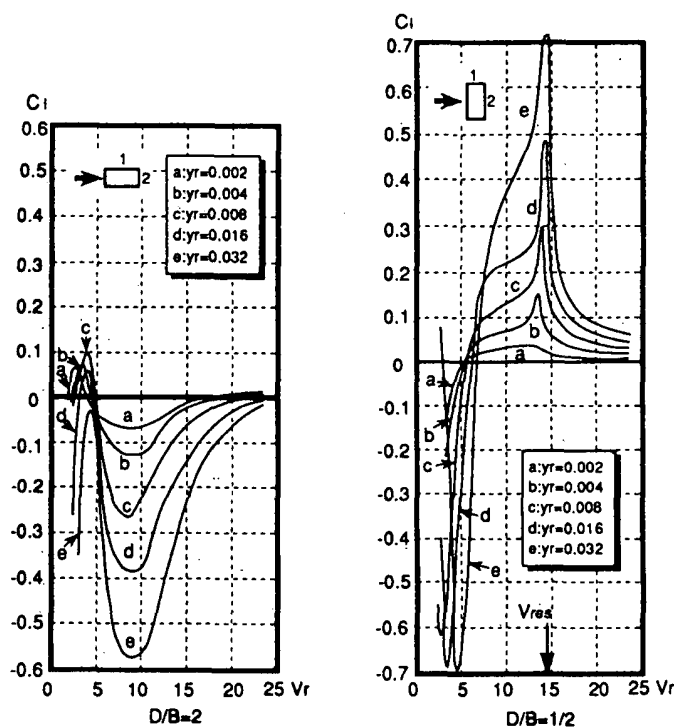

図11 谷池・西村の実験による非定常空気力
これは角柱の振動による剥離剪断層への接近と、カルマン渦によ る剪断層の振動が同期する洞励振が生じるためであると思われる。

正方形断面角柱と長方形断面角柱の結果との比較から、正方形 断面角柱でみられた現象について考察を行う。正方形断面角柱の 上層部で見られた傾向は、辺長比 0.5 の場合とょく似ている。こ れは正方形断面角柱の上層部では乱れが小さいため流れが完全に 剥離することによると思われる。また共振風速より低い風速の下 層部で見られた傾向は、辺長比2の場合と似ている。これは下層 部では乱れの強いこととカルマン渦の周期と異なる周期で角柱を 強制振動させることが、流れを再付着させることによると思われ る。正方形断面角柱で共振風速付近で急激に仕事量が正に変わる のは、角柱の振動数とカルマン渦の発生周波数が同期することに よると思われる。両者が同期しているときには、角柱の側面に沿っ た渦の流下が角柱の振動で妨げられず、剥離剪断層が再付着しな くなると思われる。このことから正方形断面角柱の下層部で見ら れた位相差 $\beta$; の急激な変化を説明できるのではないかと思われる。

\section{5.むすび}

高層建築物の空力不安定振動の要因となる非定常風圧力の特性 を明らかにするため、3次元角柱による風向直角方向の強制振動 実験を行った。用いた角柱は、再付着が生じる風方向に細長い長 方形断面角柱（边長比2）と完全剥離する風直角方向に細長い長 方形断面角柱（辺長比0.5）の2種類である。接近流は一様流に近 い状態の境界層流とした。得られた結果を下記に示す。

1）辺長比0.5の角柱ではカルマン渦の発生にともなう圧力変動が 見られたが、辺長比2の角柱では再付着のため明確には見られな かった。

2）辺長比2の角柱では共振風速付近においても非定常風圧がなす 仕事は負であり振動を抑えるように働いていた。.無次元風速 $\mathrm{Vr}=$ 4付近では風上側と風下側で大きな位相差が生じ、これが低風速 励振の原因ではないかと予測される。

3）辺長比0.5の角柱では共振風速よりもかなり低い風速で変動風 圧がなす仕事が正となり、空力不安定振動が起こりやすくなって いた。

4）正方形断面角柱の上層部に作用する非定常空気力の傾向は辺 長比0.5の全面に㗢く非定常空気力の傾向とよく一致していた。 また正方形断面角柱の下層部の共振風速以前の傾向は辺長比2の 傾向と似ていた。 


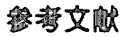

1) Bishop, R. E. D. and A. Y. Hassen: The lift and drag forces on a circular cylinder oscillating in a flowing fluid, Proc. Roy. Soc: A, Vol. 277, 1964, pp. 51.75

2) Novak,M.: Galloping Oscillations of Prismatic Structures, Proc. ASCE, Vol.98, EM 1, Feb., 1972, pp. 27-46.

3) Nakamura Y. and T. Mizota: Unsteady Lifts and Wakes of Oscillating Rectangular Prisms, Proc. ASCE, Vol.101, EM6, Dec. 1975 ,pp. $855 \cdot 871$

4）伊藤学 - 宮田利雄 - 藤沢伸光：振動する正方形断面に作用す る空気力の特性，土木学会第 30 回年次学術講演会概要集， I-208, 1975-10

5）谷池義人：高層建築物の空力不安定性に関する研究，京都大学 博士論文, 1983

6）石崎湀雄 - 谷池義人 - 近藤宏二: 角柱振動時に側面に加わる 動的な風圧力特性について（その1），日本建築学会大会学術講演 梗概集, 1982,pp.1221-1222

7）石崎湀雄 ·谷池義人：角柱振動時に側面に加わる動的な風圧 力特性について（その2），日本建築学会大会学術講演梗概集, 1983, pp. $2405 \cdot 2406$
8）石崎湀雄 - 谷池義人：角柱側面に加わる非定常な風圧力，第7 回風工学シンポジウム, 1982, pp. 83-90

9）谷池義人 - 西村宏昭 · 丸山勇祐: 正方形断面をもつ高層建築物 の空力不安定性, 京大防災年報, 第38号B-1, 1995, pp. 65·77

10）丸山勇祐 - 谷池義人 - 西村宏昭: 高層建築物の風直角方向振 動時の非定常風圧力, 日本建築学会構造系論文集,第484号, 1996 , pp. $31 \cdot 37$

11）谷池義人 - 西村宏昭: 境界層流中における高層建物の空力不 安定振動, 京大防災年報, 第36号B-1, 1993, pp. 69-78

12）西村宏昭 ·谷池義人：境界層流中における高層建物の空力不 安定振動一正方形断面をもつ高層建物の場合一, 日本建築学会構造 系論文集,第456号,1994,pp. 31-37

13）西村宏昭・谷池義人：種々の長方形断面をもつ高層建築物の 空力不安定振動, 第13回風工学シンポジウム, 1994, p p. 341-346 14）西村宏昭・谷池義人：境界層流中における高層建物の空力不 安定振動(続)－種々の長方形断面をもつ高層建物の場合一、日本建 築学会構造系論文集,第482号,1996, pp. 27-32

（1996年 9 月 10 日原稿受理，1997年 2 月 28 日採用決定） 